\title{
Illicit Cross-border Migration in Ethiopia: Causes, Patterns and Policy Responses
}

Messay Mulugeta ${ }^{1}$ and Teferee Makonnen ${ }^{2}$

\begin{abstract}
The overriding objective of this research was to assess the status, major origins and contributing factors of cross-border migration and human trafficking in Ethiopia with the intention of identifying key policy lessons to address the problem. To meet the intended objectives, desk review and key informant interview data gathering techniques were employed. The results of the assessment disclosed that Ethiopia is one of the largest origins (transit and destination as well) of trafficked persons from Africa. The most common drivers are found to be an amalgam of socioeconomic, political and environmental factors. It was also found that the journey is often dangerous leading to physical assault, sexual abuse, abduction, robbery and even death. In most destination areas, illegal migrants face restricted mobility, exploitative working conditions and harassment of different kinds. The ultimate mechanism to address the problem was found to be adequate job creation and poverty reduction through intensified development efforts involving governmental and non-governmental organizations and the private sector. Furthermore, enhanced democratization of the government system, political tolerance, improved access to legal travel authorization (visa) for safe migration, awareness creation campaigns, improved monitoring of private employment agencies, bilateral agreements with major destination countries and increased cooperation among stakeholders were found to be vital solutions to minimize illicit cross-border migration and human trafficking from Ethiopia.
\end{abstract}

Keywords: Human trafficking, illegal migration, cross-border migration, informal activity, policy response, Ethiopia

DOI: https://dx.doi.org/10.4314/ejossah.v13i2.3

\footnotetext{
${ }^{1}$ Associate Professor, College of Development Studies, Addis Ababa University

${ }^{2}$ Correspondent Author: Assistant Professor, College of Social Sciences, Addis Ababa University, Email: teferi.makonnen@aau.edu.et, Tel: +251911386076, P.O. Box: 1176 /Addis Ababa
}

This work is licensed to the publisher under the Creative Commons Attribution-NonCommercialNoDerivs License. 


\section{Background and the Rationale}

Cross-border migration and human trafficking have become realities that touch nearly all corners of the globe in the increasingly interconnected world today. Modern transportation and communication technologies have made it easier, cheaper and faster for people to move from place to place. At the same time, conflicts, poverty, income inequality, political intolerance and unemployment and/or underemployment are among the reasons that compel people to leave their homes in search of better futures for themselves and their families. As a result, the number of international migrants (persons living outside their country of birth) worldwide has continued to grow rapidly over the past 15 years reaching 244 million in 2015, up from 173 million in 2000. The number of refugees and illicit migrants is also on the increase. By the end of 2015, for example, refugee numbers mounted up to 16.1 million (OECD, 2016). This figure is likely to hike in the future owing to the appalling humanitarian situations in various parts of the world such as Libya, Myanmar, South Sudan and Syria. Other than conflicts and persecutions, as noted in OECD (2016), migration and human trafficking from developing counties, particularly Africa, is expected to continue rising because of persisting economic and well-being gaps with developed countries.

In terms of the process of migration, status of migrants and place of destination, cross-border migration has multifaceted implications which could be taken as both positive and negative outcomes of the demographic, cultural and socioeconomic circumstances of countries. OECD (2016), for example, states that officially authorized cross-border migration holds the potential to improve the lives of migrants and advance welfare in countries of origin provided that appropriate public policies are put in place. Abundant literatures show positive microeconomic impacts of remittance flows to the balance of payments in the sending countries and its importance for individuals in covering expenses for food, education, transportation, clothing and health care as well as housing construction and buying fixed assets such as land (IOM, 2005; Teferi, 2013). Betz and Simpson (2013) also argue that legal international migration has no negative impacts on native populations if properly harnessed.

In view of local and/or national perspectives, migration yields an increased level of urbanization (Amin, 1995) being an important component of rural-urban linkages, and a means of achieving economic efficiency and equity. Migration is regarded as a good cause for social diversity as well as a necessary condition for the creation and strengthening of a sense of nationhood and national unity (Buksmann, 1979 in White and Woods, 1980). Migration, through creation of diverse workforce of wide range of skills and experiences, is more likely to 
produce a creative and open-minded society to new ideas than the one made of homogenous group of people living in a place (ILO, 2011).

The problem comes when migration, particularly cross-border migration, is carried out illegally causing great adverse impacts on the migrants, sending households, migrant-origin countries and the population at destination. The most critical consequences of illegal cross-border migration, in the current global milieu, are related to security and economic aspects. Organized crimes in many destination countries seem to confirm this trend (OECD, 2016). Likewise, illegal migration may also cause an increased rate of unemployment, especially in economic stagnation period (Garson and Loizillon, 2013). Other adverse impacts pinpoint to the fact that currently there is a growing occurrence of flashpoints attributed to anti-immigrant feelings which menace the stability, solidarity and the integration in the host country. It can also be a cause and consequence of inequality and unequal development as the immigrants sometimes are unable to access, at least temporally, the existing services such as housing in their destinations (Amin, 1995).

When we see the cross-border illicit migration in the study context, it appears that Ethiopia is one of the largest origins of migrants in Africa. Several factors have been instigating Ethiopians to leave their birth places and cross international borders illicitly opting for better lives abroad. The factors include, but not limited to, high fertility (total fertility rate of about 4.6) and fast population growth (about $2.6 \% / y e a r$ ) with massive broad-base population pyramid (over $40 \%$ of the population is less than 15 years age), high prevalence of poverty $(23.4 \%$ of the population was living below poverty line in 2014/15), high inflation rate (about $10 \%$ in 2017 and food inflation hit 18.1\% high in November 2017), low agricultural productivity, erratic rainfall, and political instability and conflicts (CSA, 2013; UNDP, 2015; CSA, 2017). According to UNDP's (2015) National Human Development Report 2014, the unemployment rate in Ethiopia was very high (overall rate of unemployment is about 4.5\% and urban youth (15-29 years) unemployment rate is about $23.3 \%$ ) firing up for illegal cross-border migration from the country. Moreover, some conflicts among trans-boundary pastoralist groups along its long international boundary (about $5,328 \mathrm{~km}$ ) pose particular challenges to border management in Ethiopia thereby triggering illegal movement across the border.

Ethiopia is an origin, transit and destination for migrants subjected to human trafficking. ILO (2013) estimated that the number of trafficked Ethiopian women and children in the Middle East was as large as 130,000. In 2014, about 91,000 migrants arrived in Yemen from the Horn of Africa, of which 80 percent were 
Messay Mulugeta and Tefree Makonnen

Ethiopians who transited through Djibouti. Likewise, ILO reports indicate the presence of closer to 50,000 Ethiopians in the Republic of South Africa (RSA) where more than $95 \%$ of these young migrants entered the country through illegal cross-border migration.

For the reasons indicated above, human trafficking and unsafe migration is one of the top priority agendas of the Federal Democratic Republic Government of Ethiopia (FDRE), NGOs, CSOs, researchers and the community at large at present. The Government of Ethiopia is attempting to improve the situation and wellbeing of its people (mainly children and females), and has adopted important laws and policies to address this concern (FDRE, 2002/03). Ethiopia has ratified major international laws and policies, including the Universal Declaration of Human Rights where the right to freedom of movement is enshrined, UN Convention for the Suppression of Trafficking in Persons and Exploitation of Prostitution of Others, and UN Convention on the Rights of the Child (UNCRC). Sex and labor trafficking have been prohibited mainly through various articles of the Criminal Code and anti-trafficking legislation was endorsed with stronger punitive measures against perpetrators (FDRE, 2015). However, human trafficking and/or illicit migration have continued unabated in Ethiopia and it is with this understanding that this research was thought of to investigate the status and contributing factors of cross-border migration and human trafficking so as to identify key policy lessons to adequately address the problem.

\section{The Research Methods}

Document review and key informant interview were the two vital approaches of data collection techniques employed for the research. Document review was carried out to capture the extent and magnitude of illicit cross-border migration, the contributing factors and its implications in Ethiopia. The key documents reviewed for this research include, but not limited to, national proclamations; labor laws; human rights conventions; national policies/strategies; and reports of International Organization for Migration (IOM), International Labor Migration (ILO) and UNHCR among others.

In order to secure firsthand information from the migration affected individuals and augment the review results, twelve returnees were purposively selected and interviewed face-to-face in Addis Ababa. Other two emigrants who were living (during the interview in October 2017) in Dubai and South Africa were interviewed on telephone. Only one of the interviewees was male. Their age ranges between 23 and 41 while their education level spanned between grades 3 and 11 . Eight of them were Muslims while the remaining six were Christians. Only three 
of them were married and three of them were divorced. Ten of them migrated through illegal means by using land routes and four of them traveled legally by Ethiopian airlines. Four of the interviewees lived in Yemen, five in Saudi Arabia, one in South Africa, one in Dubai and the remaining three lived in Qatar. Eleven of the interviewees were employed as domestic workers while only three got the opportunity to work as shopkeepers. A couple of University graduates, parents of cross-border migrants and experts at federal and regional level offices that were believed to have vital information related to human trafficking and smuggling were also interviewed.

The data analysis took the form of descriptive-interpretive qualitative technique. The descriptive technique involved describing key numerical circumstances uncovered from the data to look into the prevalence and trends of the facts related to the theme of the research. The interpretative analysis focused on providing explanations to the data obtained from key informant interviews and observations.

\section{Population Movements and Illicit Emigration in Ethiopia: A Brief Literature Review}

Ethiopia is the cradle of human kind as confirmed by the ancient fossil evidences at the archeological sites in the Great Rift Valley areas (Yonas, 2012). Ethiopia is, therefore, an ancient original abode of human migration before various parts of the world were occupied. Pronounced population movement has been taking place ever since the Axumite times (around $4^{\text {th }}$ century AD) because of political instability, frequent wars and natural disasters. The Great Ethnic Migrations occurred starting from the first half of the $16^{\text {th }}$ century to mid- $17^{\text {th }}$ century that involved diverse tribal and ethnic groups of Hadya-Sidama, Oromo, Somali and Afar (Bahru, 2002).

Internal population movement accelerated in the early $20^{\text {th }}$ century with the rise of urban centers, expansion of industrial establishments and social services as well as the Italian occupation. Migration during the Imperial Era (1930-1974) was spontaneous and voluntary and individual rural outmigration during the Derg Regime was low as land redistribution by peasant associations (PAs) provided cropland to everyone who was willing and able to cultivate it, a measure that eliminated landlessness which had been a major factor in pushing people from the land during the Imperial Regime (Messay, 2012). The establishment of urban dwellers association and peasant associations accentuated the distinction between rural and urban residents that did not encourage rural-urban or urban-rural migration. Likewise, the 1975 nationalization of urban land resulted in the reduction of construction of new dwellings for rent that led to chronic shortage of 
urban housing thereby contributing for the reduction of rural-urban migration (EPMG, 1975). Another factor that had implications for reducing the level of ruralurban migration was the high level of urban unemployment and underemployment and growth of poverty (Wendt et al., 1990 in Baker, 1995).

Since 1991 the restrictions on free movement have been lifted by the present regime, but the heightened ethnic politics in the country and associated administrative barriers and lack of sound spatial distribution of the rural population have revamped the previous policy related bottlenecks of internal migration (Deverax, 2000 in Tesfaye, 2003). However, the emerging rural youth householders have been becoming virtually landless, which appears to be a big motivation to leave their domicile. Moreover, the present high rural population pressure, land degradation and diminished carrying capacity of the land together with frequent bad weather incidents have become important push factors for migration of people out of their rural residences (Dessalegn, 2004; Messay, 2012).

International migration in Ethiopia accelerated after the 1974 revolution where many refugees were attempting to escape political conflict, persecution and famine. Attempt of political centralization and oppression; the independence struggle of Eritrea from 1961-1991 that led to violent clashes in the North; the war with Somalia over the Ogaden Region in Ethiopia in 1977 and 1978; the period of Red Terror between 1976-79 generated massive refugee flows from Ethiopia (Bahru, 2002; Assefaw, 1995; Fransen \& Kuschminder, 2009). Generally, the pervasive poverty and unemployment/underemployment situation and search for better education and employment opportunities coupled with political discontent are considered to be the major causes of emigration (Teferi and Biruk, 2009 in Emerta et al., 2011).

\section{Results and Discussion}

\section{Causes of Illicit Cross-border Migration in Ethiopia}

The most common drivers of cross-border outmigration solicited from intensive literature review as well as cited by the respondents for this research were an amalgam of political reasons, economic factors (mainly youth unemployment and/or underemployment and low income), sense of responsibility towards family and strong positive perception towards living in Western and the Middle East countries. The pressure exerted on young Ethiopians by family members, peers and the community to migrate as a means to escape poverty and unemployment were of paramount importance. The relative ease of access to information about places and opportunities elsewhere through social media, presence of relatives and friends in the destination areas who often provide initial help and financial assistance 58 
obliterate irregularities of movement for migrants. The empirical information from the returnee respondents and the literatures reviewed confirm that existence of large number of illegal local brokers with networks extending to countries of destination; misinformation and false promises by brokers/traffickers; success stories of those who already migrated; and family and peer pressure were also inducing actions for cross-border outmigration.

Most respondents indicated that migrants are driven out of the country as a result of lack of livelihood opportunities, negative attitudes attached with low paying informal jobs and poor work ethics amongst the youth in Ethiopia. Similar to this finding, documentary assessment indicates that most cross-border migrations in Africa in general and in Ethiopia in particular are driven by lack of employment opportunities (Kuschminder and Siegel, 2014; FDRE, 2015; de Regt and Tafesse, 2015). Correspondingly, many Ethiopians, particularly the youth, consider outmigration as the only way to achieve a better living standard. A 2011 household survey of 1,282 households across 15 communities in Ethiopia found that 75 percent of those leaving the country were doing so to find better employment opportunities elsewhere out of Ethiopia (Kuschminder and Siegel, 2014).

The returnee respondents for this research indicated that life in Ethiopia was very severe for them as they were struggling with low wages or no income at all. Some of them had no jobs while some were underemployed. Some were selfemployed earning very meager income while some others were engaged in unprotected and insecure informal jobs. A case in point is the words of an emigrant interviewee living in South Africa (during the interview in October 2017) who disclosed his very dangerous journey to South Africa through the deserts and forests in Kenya, Tanzania and Mozambique. He '... abandoned Ethiopia because of the low paying and insecure livelihoods condition as an assistant to a minibus driver...'. He spent '....about one month travelling in a life-threatening situation and paid over sixty thousand Ethiopian Birr (about 2,205 USD at current rate of exchange) for transporters, brokers, traffickers and security persons at international borders to arrive in South Africa. The adjustment problems he faced in the destination as well as the xenophobic and robbery episodes put him at a precarious situation despite his improved livelihoods in South Africa.

By and large, life for them was precarious as a result of which they preferred illicit migration though it ended in failure and deportation for most of them. At this juncture, one may raise a question that 'why Ethiopia is unable to create job opportunities for the youth amid fast economic growth?' One possible answer for this question may be the widening income inequality between citizens, gender and 
Messay Mulugeta and Tefree Makonnen

places (UNDP, 2015) mainly because of the existing high level corruption and bribery which are verified by various reports of the FDRE and international organizations (https://www.transparency.org/country/Ethiopia). This puts the economic growth far from inclusiveness. The gender gap in education, economic and political empowerment is still high in the country (UNDP, 2015) pushing the females to look for other economic opportunities abroad. Yet again, the existing economic growth in Ethiopia seems to be geographically concentrated around big urban areas such as Addis Ababa thereby bringing spatial inequality across different geographical areas and becoming a cause for the youth to abandon their depressed birth places.

In fact, the government is trying to create adequate jobs, particularly for urban youths, under the leadership of Urban Job Creation and Food Securities Agency/Bureaus. However, the urban economy is unable to create sufficiently productive employment opportunities because of low level private sector investment in the productive sectors of the economy, particularly in manufacturing and services for an increasingly educated urban youth (UNDP, 2015). As a result, according to the university graduate key informants for this research, educated people in urban areas have difficulties finding jobs in both public and the private sectors. They commented that it is also hard to start own business owing to lack of startup capital for their projects. They underlined that this, together with other social and political dissatisfactions, is leading the youth to an infatuated dream of international migration.

As a key driving force to cross-border illicit migration, agricultural inefficiency and rural underemployment are key variables worth consideration in Ethiopia. Since agriculture is the most important economic activity in rural Ethiopia, its performance is inexorably linked to migration. Interviewed returnees, who originally migrated from rural areas, are of the same opinion that currently their families are working on miniscule and increasingly fragmented plots of land with inadequate outputs. The interviewees reported that absence of land reforms, inequalities in land ownership and other productive assets, landlessness, weatherrelated shocks, limited non-agricultural jobs in rural areas, ecological degradation, decline in soil fertility, high costs of agricultural inputs and lower/fluctuating incomes from the agricultural sector are among major factors that pushed them out.

Most interviewees are of the opinion that migration is considered to be a form of household income diversification for poor households. In terms of resource scarcity, it is mandatory that some household members migrate to other areas in search of better opportunities while other household members stay at their original location and benefit from remittances. Such a demand from the households, 
together with dissatisfaction with the rural life styles, the backbreaking donkeywork and lack of leisure time emerge out to be migration inducing factors in rural Ethiopia. Some female interviewees were not shy to explain their preference for educated and well-informed husbands in urban areas as a factor for them to leave their village behind.

On top of economic reasons, assessment of documents and interview results indicate that oppressive political context and insecurity is also an important migration driver justifying why migrants leave their specific birth places and/or their country. What justifies the respondents' claims is the fact that Ethiopia is receiving very low ratings with regard to political and civil rights from international human rights organizations. For instance, in 2016, Freedom House gave Ethiopia the lowest score on political rights attributed to the government's attempt of constricting political space during the 2015 parliamentary elections, and received a rating of 6 out of 7 on civil liberties ( 7 being the worst). Freedom House (2015) reports that Ethiopia ranked $32^{\text {nd }}$ out of 52 countries surveyed in the Ibrahim Index of African Governance, ranking below the continental average. Ethiopia is considered a 'highly corrupt' country, and ranked $103^{\text {rd }}$ out of 168 countries by Transparency International's (2015) Corruption Perceptions Index (https://www.transparency.org/cpi2015). DFID (2014) also indicated that Ethiopia has a long way to go towards establishing a functioning democracy with effective rule of law. Corruption is also widespread as government officials reportedly enjoy preferential access to credit, land leases and jobs, resulting in income inequality as reported by Freedom House (2015) and FDRE itself. Each and every one of these are dissatisfying the youth and ultimately pushing them abroad.

The interview results of a study by de Regt (2007) has interesting story in connection to this:

Tsehai is a 22-year old girl, born in a small Ethiopian town close to the Sudanese border. She is the youngest in a big family... She was forced to leave her home town after having participated in student demonstrations against the government. Tsehai fled to Addis [Ababa], where she was arrested and detained. ... when she was released she decided to flee. She [went to] ... Djibouti, where Tsehai took up work as a domestic worker for a Somali family, and later became a cook for a Frenchman. Three years later she decided to move on to Yemen ... She was smuggled by boat from Djibouti to a small town on the Red Sea coast. 
Civil war and political turmoil has characterized Ethiopia in 1970s and 1980s (Bahru, 2002) as a result of which many Ethiopians were forced to flee their home to escape violence arising from the civil war. As indicated by Bariagabir (1995) "...violence had been an important means of seeking political aims and at the same time ensuing cycles of reprisals and counter reprisals that generated refugee flows out of Ethiopia". Even currently, continued periodic outbreaks of public protests and conflicts have been causing massive population relocations that could result in cross-border migration, too. A case in point is the Oromo-Somali conflict in 2017 that resulted in relocation of hundreds of thousands of Oromos from Ethio-Somali Region, which, in turn, has great implications in initiating further illicit crossborder human trafficking. The contribution of some armed organizations such as Ogaden National Liberation Front (ONLF), Oromo Liberation Front (OLF) and Ginbot 7, designated as terrorist organizations by the government and banned since 2011 (EIU, 2015), have also ramifications in migration in one way or the other.

The role of returnee migrants is found to be one of the vital driving factors for the expansion of cross-border illicit migration from Ethiopia. According to some interviewees, returning migrants were creating false impressions to potential migrants and their families. They underplay the challenges and exaggerate the opportunities in destination areas. They tend to hide the other side of the story: the risky travels, labor abuses, sexual assault, insufficient payment and beating. They talk about the neatness of cities, multistory skyscrapers, transpiration and housing facilities, the varieties and quality of dish, and above all the money they make abroad. These, together with other push factors, activate the youth to go abroad and long for grasping the dream opportunity.

The lure and enticement presented to potential migrants from recruiting agents and brokers is another vital factor in expanding cross-border migration in Ethiopia. According to some returnee informants, the brokers were very verbose and have very high ability in persuasion. They sometimes plead to convince the migrants not to overlook the golden opportunities overseas. The brokers sometimes coax sweet-talks to win the migrants' hearts. Likewise, the role of religious pilgrimage was found to be another vital cause for migration. In this case, the journey is relatively safe and migrants travel as if they go for religious reasons, though, the main purpose of the journey was economic migration to the Middle East. They use the Umra and the Hajj pilgrimages as a pretext to go to Saudi Arabia and then to move from there to other Arab countries, a strategy that is used even by those who are not Muslims. A good example is a Christian girl, returnee key informant for this study, originally from Mariye (South Wollo), but moved to 
the Middle East through the alleged pilgrimage to Mecca. Similar to this finding, there are various reports and research findings (de Regt, 2007; de Regt and Tafesse, 2015) which indicate the number of illegal Ethiopian migrants to the Middle East under the pretext of pilgrimage.

Similar to the findings by Girma et al. (2008), failure to succeed in educational endeavors was among the motivation factors listed by key informants. Outmigration could also be encouraged by the outward oriented education that influences the taste of youth and that prepares them to take up urban activities, inability of families to pay for tertiary education and availability of employment opportunities abroad even for persons with low level or no education. A first degree graduate in Material Engineering, from a well-to-do family was among the university graduate key informants for this research who was waiting for a husband she had known over social media and was meant to take her to Europe in marriage arrangement. This shows that there is a tendency for qualified youths to go abroad which could contribute to outmigration of young people.

The 'culture of migration' is another key factor underlying high levels of illegal cross-border migration and human trafficking in Ethiopia. Cross- border migration is considered as a source of personal, social and material success in most communities and creates wrong role models for the younger generation. The 'culture of migration' for supporting families has emerged in several areas in Ethiopia. A case in point is the words of an elderly who have two children living abroad. He was proud to say "...thanks God, I sent my two girls to Dubai, and hopefully they will pay me back the challenges I went through to bring them up'. Likewise, another returnee key informant stated that sometimes husbands create pressure on young wives to consider migration as a vital means to support the household at the expense of their education, marriage and children. Numerous similar studies (de Regt, 2007; ILO, 2011; Makonnen, 2013) indicate that crossborder migration in Ethiopia is undertaken as part of a family welfare strategy for sustenance and economic improvement not only by an individual decision but also as a family frame of thought.

Interviews with returnees and key informants at Federal and Regional offices as well as results of document analysis indicate the importance of factors on the demand-side in expanding cross-border illicit migration in Ethiopia. The oildependent better-performing economies in the Middle East (IMF, 2016) have enhanced the living standards of their citizens where there appears shortage of labor on the low-paying, informal and perilous jobs. Most Ethiopians in the Middle East are employed in unskilled manual labors like domestic works, looking after herds, driving vehicles, daily labor, shopkeeping, guarding and cleaning. In fact, 
Messay Mulugeta and Tefree Makonnen

there are very few entrepreneurs and housewives (ILO, 2017). In order to fill in the shortage of labor for domestic works, these countries of destination are looking towards Ethiopian labor markets where they have a significant comparative advantage in terms of payment and living condition offers. Similarly, law enforcement agencies in the destination countries have not given adequate and timely attention to trafficking as a serious problem (de Regt, 2007; de Regt and Tafesse, 2015). This has given a free ground for illicit traffickers. Moreover, unskilled as well as skilled young people in Ethiopia found migration as lucrative opportunity though in most cases it is ending up in misfortunes and catastrophes.

Another essential driver of cross-border migration was found to be family dysfunction. As a result of dissolution of marriage, widows and divorcees may opt for migration legally or illicitly to support their children or as a transition period to start a new way of life. A case in point is a brief life history of a 27-year old key respondent who indicated her disappointment owing to unexpected divorce when she was 23. As a result of the divorce she decided to go to Dubai not only as a means to put out of her mind the distressing situations related to her family breakup but also to generate money to support her child. In effect, she managed to make some money under dishonorable working conditions in Dubai. She said "...I swear to God not to go back to Dubai because of the disgraceful working situations for unskilled migrants. I prefer to die of hunger in my country. I have lately realized that I can work harder and earn better here..." Similar to this finding, Girma et al. (2008) indicates that family conflicts and youth misbehavior are major contributory factors for illicit migration in Ethiopia.

\section{Ethiopia as a Migration Origin, Transit and Destination Country}

Ethiopia is a country of origin, transit and destination for illicit cross-border migration. It is one of the major labor exporting and the largest refugee hosting countries in Africa (ILO, 2017). International migration in Ethiopia has been accelerating since the 1974 revolution when many refugees attempted to escape political persecution and famine (Assefaw, 1995; Fransen \& Kushminder, 2009). These pushed millions of Ethiopians to the status of Diaspora population of one of the largest of African countries. Though exact figures are not available, the number of Ethiopian diasporas are estimated to be around three million, with large numbers reported in the Middle East (Saudi Arabia and Yemen), USA, Canada and Europe as well as in Sudan, Kenya, South Africa and Botswana (Frouws, 2014). (UNDESA, 2015) found that in 2013 the top five countries for Ethiopians living abroad were USA (179,979 Ethiopian-born migrants); Israel (81,880); Sudan $(62,431)$; Italy $(31,547)$ and Saudi Arabia $(28,048)$. It was estimated that the seven 
OECD countries with the largest Ethiopian-born populations in recent years were USA (195,805); Israel (85,870); Italy (30,596); Canada (24,535); Sweden $(15,494)$; UK $(12,000)$ and Australia $(10,850)$. As indicated in Carter and Rohwerder (2016), a large number of Ethiopian refugees and asylum seekers, about 30,662, are found in Kenya. Other countries that host substantial number of Ethiopian refugees and asylum seekers are Sudan 18,335; Yemen, 13,787; Egypt, 6,278; South Africa, 5,538; South Sudan, 4,202 and Uganda 2,502. USA hosted 10,508 Ethiopian refugees at the end of 2012. According to Carter and Rohwerder (2016), although it is difficult to obtain an accurate picture of the migration situation in Ethiopia, because of lack of proper documentation of irregular migration, there are about 88,149 Ethiopian refugees and 72,278 asylum seekers worldwide (Kuschminder and Siegel, 2014; Kuschminder, 2014).

Studies indicate that (Teferi, 2013; ILO, 2017) most Ethiopian cross-border migrants (both legal and illicit) are young (mostly between 18 and 25), slightly educated, single and unemployed/underemployed (Frouws, 2014; Kuschminder and Siegel, 2014). As regards to the ethnic composition, most migrants to the Middle East are Oromos. ILOs (2013) survey in collaboration with the Ministry of Social and Labor Affairs/MoLSA/ found in Yemen that 50 percent of migrants and 57percent of returnees were Oromos (Frouws, 2014). The next largest group of migrants to the Middle East were Amharas who make up 17percent of the current migrants and 24 percent of returnees. It should be noted, however, that 2014 IOM figures showed that the largest group of returnees from Saudi Arabia are Amharas. Surprisingly, all the interviewees for this research were also Oromos and Amharas coming from non-cash crop producing area such as Arsi, North Shewa, Gojam and Wollo. More than 80 percent of those surveyed had heard about the possibility of extortion and robbery, exhaustion, dehydration, starvation and sleep deprivation, physical violence, kidnapping for ransom, degrading treatment, and verbal and sexual abuse. Despite the increasing risks, 42 percent believed that the benefits of migration were worth the risks (Frouws, 2014).

Ethiopia hosts the largest number of refugees in Africa. The Ethiopian government generally maintains open borders for refugees seeking protection in the country. Many migrants, refugees and asylum-seekers entering Ethiopia are escaping political and civil unrest as well as harsh or undesirable conditions (e.g. drought) in neighboring countries. According to UNHCR (2017) and UNICEF (2017), as of April 2017, the number of registered refugees and asylum-seekers in Ethiopia was 829,925 persons. About $48 \%$ of the refugees and asylum-seekers were females, while the number of children (less than or equals to 11-year old) were $40.1 \%$. The proportion of elderly (60+) population was 1.1 percent. 
Ethiopia provides protection to refugees from different countries including Eritrea, Somalia, South Sudan, Sudan and Yemen. Refugees and asylum seekers are generally expected by the government to reside in refugee camps although some are allowed to reside in urban areas for special circumstances such as medical, security or humanitarian reasons. The government has allocated land for refugee camps around Addis Ababa, Assosa, Dollo Ado, Gambella, Jijiga, Melka Dida, Semera and Shire areas (UNHCR, 2017). The Ethiopian government's 'Out of Camp Policy was, introduced in 2010 in collaboration with UNHCR to enable Eritrean refugees in particular to live in Addis Ababa and other locations provided that they have the necessary means to financially support themselves and have no criminal record/s while in refugee camps.

Ethiopians are also currently returning to their country due to various reasons such as to reunite with family or friends, for investment or due to repatriation and deportation. Over 8,000 Ethiopian nationals returned to the country from Yemen between April 2015 and April 2016. Thousands of Ethiopians have also compulsorily returned to Ethiopia from Saudi Arabia in 2017. More importantly, the Ethiopian government has introduced various initiatives to facilitate temporary and permanent return and reintegration of diaspora Ethiopians and returnees. A case in point is the Persons of Ethiopian Origin Identity Card (PEOIC) which was introduced in 2002 granting diaspora Ethiopians nearly the same rights as local citizens.

As indicated in ICMPD (2008), owing to its strategic location in the Horn of Africa and the presence of a well-operating Ethiopian Airlines, Ethiopia has become a major transit point and migration hub for Eastern African migration routes of transit and irregular migration movements. It appears to be a hub on three land routes of which one leads from the Horn of Africa via Sudan, Chad and Libya to the Mediterranean Sea; the other through Somalia to Yemen across the Gulf of Aden and the third to South Africa through Tanzania. Bole International Airport is also reported to be a hub of transit and irregular migration on the air route leading to Europe and the Middle East including irregular migration flows from Asia transiting through Africa. Cross-border migrants from many neighboring countries (such as Eritrea, Somalia and South Sudan) transit through Ethiopia in their attempts to reach developed countries via Sudan and Egypt or Libya. Sometimes refugees leave camps voluntarily or are lured to leave and cross into Sudan to join other migrants and asylum-seekers on the western/northern routes towards Europe.

Major sources of cross-border migrants, the recruitment processes and migration routes 
Cross-border migrants from Ethiopia particularly to the Middle East originate from various areas, mostly from urban areas and their environs, including Addis Ababa, Dire Dawa, Adama, Dessie, Assela, Robe, Jimma, Hawassa, Shashemene Bahir Dar, Debre Markos, Gondar, and Mekelle, Other towns/surrounding areas with growing incidence of migration and trafficking are Adama, Ambo, Fiche, Chancho, Hirna, Gelemso, Shewa Robit, Debre Birhan and Debre Tabor. In fact, it is hard to mention any non-migrant sending locale in Ethiopia owing to the multiple factors mentioned herein before. A significant number of urban and rural people come from different parts of the country to transit through the cities of Addis Ababa, Dire Dawa and Bahir Dar for emigration. The returnee key informants for this research, for example, had come to Addis Ababa to access brokers who had assisted them in getting passport and visa. The role of brokers is vital here not only in processing passport and visa, but also for arranging temporary shelter for the potential migrants who may not have information where and how to stay in Addis Ababa. According to the key informants, the shelters are very low standard, congested and untidy.

Another common transit point is Dire Dawa, where people of both sexes from rural and urban communities come from all over the country with the intention of migrating to Djibouti or to pass to Yemen and Saudi Arabia. Most of those who transit in Dire Dawa come from Arsi-Bale, Jimma, Western Hararghe and Wollo, while some come from North Shewa, Tigray, Gondar and Gojam. Young girls from Dire Dawa also use Djibouti and Yemen as transit countries to move on to other countries of destination. A third major transit point is Bahir Dar where migrants move on to Metema on their route to the Sudan. Most of those using this route are reported to be rural migrants from around Jimma and SNNPR (Southern Nations, Nationalities and Peoples Region). 


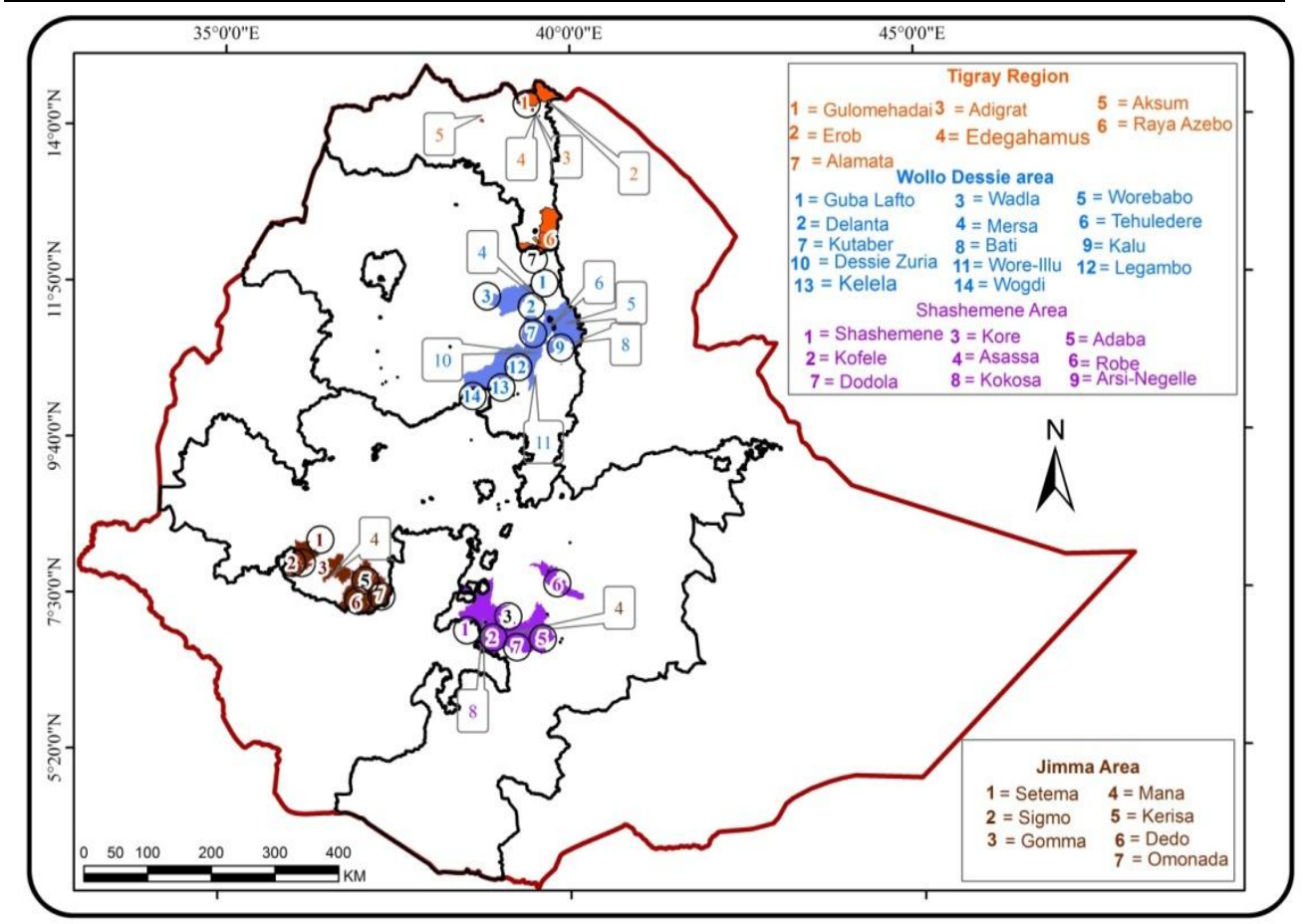

Figure 1: Major cross-border migrant source areas in Ethiopia

The interviews held with key informants and studies of ILO (2011) using information provided by returnees, parents of migrants and community members, indicated that there are different actors in the recruitment and trafficking of potential cross-border migrants. It is reported by the informants that recruitment of migrants may be initiated by different people, including local brokers, returnees and visitors from destination countries, relatives and friends and licensed or unlicensed agencies. Local brokers are individuals going around at the community level lobbying potential migrants from communities. These people form key links in the migration process by providing migrants with important information about opportunities abroad and the process of migration. They promote their services by using success stories of people they have already sent abroad. They also actively disseminate information about employment opportunities in destination countries 
and routes that result in successful migration, and returns and benefits of migration.

Next to the local brokers come brokers for transportation, harboring and smuggling migrants across borders. These types of traffickers receive the victims from local brokers, usually in groups, and are likely to transfer them to other traffickers within the network before the migrants reach the destination country. Such brokers are reported to be located on the desert and sea routes. Most of these are returnees or contraband merchants who know the desert routes very well and have established contacts with brokers in transit countries, such as Djibouti and Yemen, and other destination countries in the Middle East. These individuals function by securing protection from local authorities and armies patrolling the desert routes.

Other partakers in the cross-border migration process are returnees, visitors and their representatives. Returnees are involved at various stages of trafficking processes with different capacities. While some might just facilitate migration for a fee through their contacts in Ethiopia or in the country of destination, others establish a trafficking network for handling the whole process. Often times, these returnees start brokering by helping a sibling, relative, friend or a neighbor to emigrate and thereby continue the practice as local brokers or unlicensed agents thereafter. These kinds of traffickers are very common in communities where a 'culture of migration' has emerged. Returnees are also reported to be active and successful recruiters as they are members of the same community and can tell success stories of their own more persuasively.

A case in point is the statements on telephone interview with an Ethiopian migrant girl living in Dubai:

'My neighbor, who had lived here [Dubai] for about 10 years, had introduced me about the opportunity in Dubai when I was a $3^{\text {rd }}$ year student at Rift Valley University. She told me that she was a shop attendant here [Dubai] where she had made quite enough money to start her business in Adama. I was highly influenced, dropped my university study and arrived here (Dubai) through very challenging processes. But what I faced here is quite different and at this time I am regretting about my decision. I am planning to move to Germany through marriage arrangement, but I don't think it is that simple...' 
Messay Mulugeta and Tefree Makonnen

The plan of the interviewee to move out to Germany (re-trafficking) explicates the empirical findings of ILO (2008: 21)'s that ' $\ldots$ at the destination of their journey, the skills of migrant workers [trafficked victims] are also devalued and employment is largely informal. Moreover, many trafficked victims are at risk of being re-trafficked ... as they cannot find work.'

Once recruited, the migrants are required to move in one of the various routes to the destination areas. There are three main irregular routes and one regular route for cross-border migrants from Ethiopia. The first one is the eastern irregular route via the desert and sea route from Afar, Dire Dawa, Jijiga, through Djibouti or Somalia to Yemen and onwards. The second route is the Southern irregular route that is an overland course from Moyale through Kenya and on towards to the Republic of South Africa (RSA). The third one is the northwestern irregular route which is overland route from Metema through the Sudan and Egypt towards Libya and then by sea to Europe. The regular route involves flight from Bole International Airport to major destination countries.

The process of trafficking Ethiopians ends in the hands of destination area traffickers. According to the returnee informants, the destination traffickers consist of individuals who make use of the vulnerability, solitude and helplessness of migrants in destination countries. They put the migrants in situations of vulnerability, abuse and exploitation by means of deception, control and intimidation. Since these traffickers are residents of the destination countries and have strong links with local and unlicensed agents and/or friends and family members, they often handover the migrants to these groups to complete the process at the destination. The destination-point traffickers could be former Ethiopian migrants who became traffickers. They could act as sponsors because they are well-established residents in destination areas, have strong links with chain of brokers and smugglers in Ethiopia, welcome them upon arrival, provide them with shelter, place them as domestic workers and collect their salary directly from the employer. A case in point is the telephone interviewee above who indicated that she forcibly signed an agreement of two years to receive her salary form the hands of the broker, not directly from her employer. She had given her passport to the broker as a security against the agreement.

\section{Major Policy and Legal Responses to Illicit Migration in Ethiopia}

According to an interview data obtained from Private Employment Agency Licensing Team (PEALT) in the Ministry of Labor and Social Affairs, human trafficking in Ethiopia is a multifaceted problem that requires multidimensional solutions with involvement of different actors. Similar to this, UNODC (2008) 
states that a comprehensive anti-trafficking response (known as the Framework for Action) needs to be set in place in order to adequately address the issue of human trafficking. The framework promotes prosecution, protection and prevention through national and international cooperation and coordination.

In view of this framework for action, a major motivation for trafficking in Ethiopia could be inadequate application and enforcement of labor standards, including absence of respect for and consent to minimum working conditions in Ethiopia as well as in the destination countries. The fact that Ethiopia and destination countries tolerate restriction of freedom of movement, long working hours, poor, inadequate health and safety measures, substandard wages and housing provisions contribute for expansion of market for trafficked migrants who have no choice but to labor in conditions within intolerable and illegal employment environments. Another factor that contributes to the proliferation of trafficking in view of the framework is the absence of labor inspection and monitoring in countries of destination. This situation is especially true in already marginalized sectors such as looking after cattle and domestic services.

The interview data obtained from PEALT and related literatures show that the government of Ethiopia is doing its level best to protect the rights and well-being of Ethiopian migrants in destination areas. The activities include awareness creation on human trafficking, licensing and monitoring labor agents, and patrolling borderlines. In fact, there is no comprehensive victim-sensitive compensation mechanism for the victimized migrants in each destination country which could be solved through bilateral agreement between Ethiopia and the destination countries. The statements of the PEALT interviewee indicates that a well-balanced bilateral agreement ensures not only to adequately redress the problem, but also to avoid secondary victimization, in which the migrants are treated as criminals not as victims, risk detention and deportation if the employer notifies police that the worker has absconded. The problem is multidimensional that even where justice is about to be served they cannot explain what happened to them to police and service providers due to language barrier. There is also an attempt of providing the returnee victims with comprehensive and immediate services for the injuries and trauma they survived.

Adopting and implementing adequate legislation and policy to hold traffickers responsible for their criminal act is an important response to fight the problem of human trafficking. In fact, successful prosecution of traffickers often requires an intensive and systematic testimony of victims. Effective response should provide victims with adequate security for their safety when they witness for the prosecution of traffickers or criminal networks. In connection with this, MoLSA 
Messay Mulugeta and Tefree Makonnen

interviewees indicated that the Government of Ethiopia is doing its level best in enforcing anti-trafficking laws that safeguard persons who give testimony on such issues. However, trafficking offenses remained a significant concern preventing the enforcement of anti-trafficking laws in Ethiopia because prosecution has been complicated as a result of bribery. Interviewees underlined that since trafficking is a transnational problem; international cooperation is an essential component of effective prosecution. It is critical that countries of origin, transit and destination should work together to ensure the collection of adequate evidences for effective prosecution and comprehensive provision of services so that victims could fully and effectively participate in the prosecution of traffickers.

As a result of human rights violations against Ethiopian migrants in the Middle East and Gulf states, since October 2013 the Ethiopian government has imposed a temporary ban on labor migration to these countries. Recently the ban was lifted and a new legislation was introduced on labor migration, with a number of conditions placed on private employment agencies (PEAs). It also sets preconditions against those who are migrating to have the required skills and training. Although the ban was assumed at reducing the options to potential migrants, it unfortunately increased the likelihood that potential migrants turn to migrant smuggling operations and become vulnerable to exploitation and fraud.

In an attempt to prevent exploitation of Ethiopian migrants, MoLSA has introduced requirements for migrant workers to produce foreign employment contracts by which they verify employers' compliance with national law. Although this measure regulates labor migration, it does not hinder trafficking and even exploitation. In relation to this, some returnee interviewees stated that they were forced to sign modified contracts other than what they did in Addis Ababa upon their arrival in destination countries. They argued that the new contracts are prepared in favor of employers and/or agencies. According to the interviewees there are also times when the contracts are entirely changed and/or cancelled. An interview with PEALT shows that MoLSA has sought to establish contract frameworks with countries in the Middle East which, however, have been reluctant to accept it. The interviewees also indicated that there is deceitful employment and travel agents which attempt to deceive potential migrants with fraudulent job offers from the Middle East.

Ethiopia has also ratified various international legislations relevant to mixed migration and protection of human rights of migrants and refugees. These include the UN Convention for the Suppression of the Traffic in Persons and the Exploitation of Prostitution of Others (1949); the Convention Relating to the Status of Refugees (1951) and its 1967 Protocol (Ethiopia maintains reservations 
regarding refugees' employment); ILO Convention No. 105 on the Abolition of Forced Labor (1957); OAU Convention Governing Specific Aspects of Refugee Problems in Africa (1969); the African Charter on Human and Peoples' Rights (1986); International Covenant on Civil and Political Rights (1966); International Covenant on Economic, Social and Cultural Rights (1966); United Nations Convention against Torture and Other Cruel, Inhuman or Degrading Treatment or Punishment; International Covenant on Civil and Political Rights; International Covenant on Economic, Social and Cultural Rights; International Covenant on the Elimination of all Forms of Discrimination against Women; International Convention on the Elimination of All Forms of Racial Discrimination; United Nation's Convention on the Rights of Children; African Union Convention for the Protection and Assistance of Internally Displaced Persons in Africa; International Convention for the Safety of Life at Sea; ILO Convention No. 181 on Private Employment Agencies (1997); and the UN Convention against Transnational Organized Crime (2000).

National legislations relevant to mixed migration and protection of human rights of migrants include the Criminal Code No 414/2004, Refugee Proclamation No. 409/2004; Convention on Forced or Compulsory Labor Ratification (Proclamation No. 336/2003); and Employment Exchange Services Proclamation No. 632/2009. The very recent compressive and punitive legal framework is the proclamation on prevention and suspension of trafficking in person and smuggling of migrants (i.e. Proclamation No. 909/2015). This proclamation stipulates that human trafficking, especially trafficking and smuggling women and children, is a very serious crime and leads to a vital punitive measures up to death penalty. Any person within the Ethiopian territory or outside who recruits, transports, transfers, harbors or receives individuals or a group for the purpose of exploitation shall be punishable with rigorous imprisonment. The punishment is more severe if it is committed against children, women and anyone with mental or physical impairment; committed by using drugs, medicine or weapons as a means; done by public official or civil servant by abusing power; and committed by a person who is considered as parent, brother, sister, guardian or a person having a power on the victim and resulted in physical or psychological harm on the victim.

Ethiopia signed Memorandum of Understanding (MoU) with Djibouti, Jordan, Kuwait, Qatar and Saudi Arabia in order to protect its migrant workers in these countries. According to an interview made with an expert in PEALT of MoLSA (in September 2017), discussion was going on with other Middle East countries such as Lebanon, Oman and United Arab Emirates to sign a similar MoU on human trafficking and migrant laborers. Moreover, Ethiopia and Kenya have a bilateral 
open border policy which allows citizens to cross borders without visas. Likewise, the FDRE Diaspora Policy was launched in 2013 (MoFA, 2013) to guide the country's diaspora affairs and in particular to maximize the economic potential and skills of Ethiopian diaspora for national development. The policy promotes diaspora engagement and participation in investment, trade and tourism, and thus encourages foreign currency inflow as well as knowledge and technology transfer.

\section{Concluding Remarks and the Way Forward}

Cross-border migration and human trafficking in Ethiopia is pervasive; the causes are varied and multifaceted; the stakeholders are numerous and the consequences are diverse. Consequently, the remedies could be multidimensional. Cross-border migration and human trafficking have become realities affecting nearly all corners of the country. Modern transportation and communication technologies have made it easier, cheaper and faster for Ethiopian youth to access superficial information about destination countries and then decide to move on unsafe routes. Youth unemployment/underemployment, conflicts, poverty, income inequality, household indebtedness, population pressure, lack of good governance, landlessness, low agricultural productivity and agro-climatic disasters, low wages and insecure informal activities are among the reasons that compel the youth to leave their homes in search of better lives for themselves and their families.

Generally, cross-border migration has been considered as the best survival strategy for the youth though they are aware that living abroad under insecure condition is sickening and disgusting. This can be observed from the fact that unsafe migration is still continuing unabated though there are adequate publicity of human misery and deaths on the way to destination countries.

In order to address the existing unpleasant and embarrassing situations related to irregular migration and human trafficking in Ethiopia, inclusive development interventions, enhanced agricultural production systems, rule of law, proper job creation strategies, and improved awareness creation approaches are recommended to be in place. The provision of government loans and revolving funds with strict follow-up on projects that are carried out by the youth, has to be given attention by concerned government sector offices such as the Federal Urban Job Creation and Food Security Agency. It is exigent and vital for the government to enhance good governance and develop democratic culture and political tolerance to curb the prevalence of the problem. It looks a critical time for the government, CSOs, NGOs, researchers, religious organizations, community leaders and political parties to indoctrinate Ethiopian youth to look for opportunities at home rather than longing for unsafe irregular migration. Moreover, Ethiopia should put in place 
continuous awareness creation campaigns on the risks of illicit migration to fight human trafficking and illegal cross-border migration through the media, formal and informal education means, religious institutions and teachings and other means necessary.

Cross-border co-operation should be enhanced between Ethiopia and its neighboring countries on issues like harmonization of border control procedures and joint patrols and bilateral exchange of information related to human trafficking and smuggling. Likewise, although fragmented elements of migration policy do exist in different proclamations and policies, Ethiopia does not have a concerted policy framework on migration. Therefore, it should put in place a comprehensive national migration policy. The passport and visa procedures in Ethiopia should also be modernized, decentralized and accessible at least at all regional towns.

In fact, it is quite clear that reducing human trafficking through promotion of safe migration may have positive outcomes to both migrant-sending families and the migrants themselves. ILO (2013) states that, "legal labor migration channels contribute to reducing ... the smuggling of migrants". Through safe migration, potential migrants can be made aware of issues and facts to avoid likely risks, abuses and exploitations prior to, during and after migration. Similarly, it is essential to work towards supporting the migrants to acquire the necessary skills for the intended employment abroad. In this regard, need-based work related and language trainings to potential migrants are of pivotal importance.

Bilateral agreements between Ethiopia and all of the major migration destination countries in the Middle East with regards to enhancing co-operation against human trafficking and constant monitoring of the implementation of the agreement would be a sensible mechanism to ensure the protection of labor migrants.

With regard to rehabilitating victimized returnees, it is vital to establish adequate rehabilitation centers and raise fund that could be used to assist Ethiopian distressed returnees. Comprehensive and immediate services such as temporary shelter, medical and psychosocial care, legal aid, food, clothing, and reintegration schemes should be available to victims. Particular attention should be given to the specific needs of women and children victims. The government, NGOs and CSOs can play key roles in establishing rehabilitation centers where victimized returnees could recover from the ill-treatment and trauma they encountered in the destination areas.

As regards to prosecution, even in circumstances where criminal acts are reported and investigation has been initiated; only very few cases end up in prosecution. Hence, effective prosecution of human trafficking calls for more 
Messay Mulugeta and Tefree Makonnen

works and concerted efforts of the community, the victims, the police, the administrative and legal authorities and other relevant bodies.

Acknowledgement: The researchers are grateful to the study participants, Consortium of Christian Relief and Development Association (CCRDA), and the anonymous reviewers. 


\section{References}

Amin, S. (1995). "Migration in Contemporary Africa" In Jonathan, B and Tade, A.A., editors. The Migration Experience in Africa. Sweden: Nordiska Afrikainstitutet.

Bahru, Z. (2002). A History of Modern Ethiopia: 1855-1991(2 $2^{\text {nd }}$ ed.). Eastern African Studies.

Baker, J. (1995). "Migration in Ethiopia and the role of the state" in Jonathan, B. and Tade, A.A., editors. The Migration Experience in Africa. Sweden: Nordiska Afrikainstitutet.

Bariagaber, A. (1995). "Linking political violence and refugee situations in the Horn of Africa: an Empirical Approach." Journal of International Migration, 33 (2): 209-234.

Betz, W. and Simpson, N. B. (2013). "The effects of international migration on the well-being of native populations in Europe." IZA Journal of Migration, 2(12):1-21.

Carter, B. and Rohwerder, B. (2016). Rapid Fragility and Migration Assessment for Ethiopia: Rapid Literature Review (GSDRC report). Retrieved from https://assets.publishing.service.gov.uk

Central Statistical Agency. (2017). National Statistical Development Strategy of Ethiopia. Addis Ababa.

Central Statistical Agency/CSA/. (2013). Population Projections for Ethiopia for 2007-2037 [Inter-Censal Population Survey]. Addis Ababa.

de Regt, M. \& Tafesse, M. (2015). "Deported before experiencing the good sides of migration: Ethiopians returning from Saudi Arabia." African and Black Diaspora: An International Journal, 9(2): 1-15.

de Regt, Marina. (2007). Ethiopian Women in the Middle East: The Case of Migrant Domestic Workers in Yemen (Paper for the African Studies Centre seminar of 15 February 2007). University of Amsterdam.

Department for International Development /DFID/. (2014). Operational Plan 2011-2016: DFID Ethiopia. London: DFID. Retrieved from https://www.gov.uk.

Dessalegn, R. (2004). Searching for Tenure Security? The Land System and New Policy Initiatives in Ethiopia. (FSS Discussion Paper No. 12). Addis Ababa: Forum for Social Studies.

Economist Intelligence Unit /EIU/. (2015). Ethiopia Economic and Political Outlook. (Country Report Ethiopia 4th Quarter 2015). London: Economist Intelligence Unit. 
Emerta, A., Ahmed, G., Aberra, k., and Makonnen, T. (2011). "International Migration, remittance and poverty alleviation in Ethiopia". Ethiopian Journal of Development Research, 33(1).

Ethiopian Provisional Military Government /EPMG/. (1975). Public Ownership of Rural Lands Proclamation No 31. Addis Ababa.

Federal Democratic Republic of Ethiopia /FDRE/. (2002). Federal Democratic Republic of Ethiopia Food Security Strategy. Addis Ababa.

Federal Democratic Republic of Ethiopia /FDRE/. (2003). Resettlement (Access to Improved Land) Program Implementation Manual (Volume II). Addis Ababa.

Federal Democratic Republic of Ethiopia /FDRE/. (2015). Proclamation for the Prevention and Suppression of Trafficking in Persons and Smuggling of Migrants (Proclamation No. 909/2015). Addis Ababa

Fransen, S. \& Kuschminder, K. (2009). Migration in Ethiopia: History, Current Trends and Future Prospects (Paper Series: Migration and Development Country Profiles). Maastricht Graduate School of Governance.

Freedom House. (2015). Freedom in the World 2015: Highlights from Freedom House's Annual Report on Political Rights and Civil Liberties. Washington, D .C.

Frouws, B. (2014). Blinded by Hope: Knowledge, Attitudes and Practices of Ethiopian Migrants. Nairobi: The Regional Mixed Migration Secretariat.

Garson, J. P. and Loizillon, A. (2013). Changes and Challenges: Europe and Migration from 1950 to Present (In the Economic and Social Aspects of Migration, the Conference Jointly Organized by European Commission and OECD). Brussels.

Girma, k., Asfaw, W., Zeleke, G. and Scott, D. (2008). The Nexus of Migration, HIV/AIDS and Food Security in Ethiopia. Addis Ababa: Global Mountain Program.

International Centre for Migration Policy Development (ICMPD). (2008). East Africa Migration Route Initiative Gaps \& Needs Analysis Project Country Reports: Ethiopia, Kenya, Libya. Vienna.

International Labor Organization /ILO/. (2008). ILO Action against Trafficking in Human Beings. Geneva.

International Labor Organization /ILO/. (2011). Trafficking in Persons Overseas for Labor Purposes: The Case of Ethiopian Domestic Workers. (Research by Play Therapy Africa Ltd and ILO Country Office Addis Ababa in Collaboration with the Ministry of Labor and Social Affairs 
(MoLSA) the Ethiopian Employers' Federation and the Confederation of Ethiopian Trade Unions). Addis Ababa.

International Labor Organization /ILO/. (2013). Global Employment Trends: Recovering from a second jobs dip. Geneva: International Labor Office.

International Labor Organization /ILO/. (2017). Promote Effective Labor Migration Governance in Ethiopia: Program Achievement. Geneva: International Labor Organization.

International Monetary Fund /IMF/. (2016). Middle East and North Africa Regional Economic Outlook. Cairo.

International Organization for Migration /IOM/. (2005). Migration Development Nexus: Evidence and Policy Options (IOM Migration Research Series No. 8). Geneva.

Kuschminder, K. \& Siegel, M. (2014). Migration \& Development: A World in Motion (Ethiopia Country Report). Maastricht University and United Nations University.

Kuschminder, K. (2014). Shattered Dreams and Return of Vulnerability: Challenges of Ethiopian Female Migration to the Middle East (IS Academy Policy Brief N.18). Maastricht: Maastricht Graduate School of Governance.

Messay, M. (2012). Resettlement and Food Security Nexus in Ethiopia: Case Studies form Nonno District, Central Ethiopia (PhD Dissertation). Addis Ababa University: College of Social Sciences.

Ministry of Foreign Affairs /MoFA/. (2013). Federal Democratic Republic of Ethiopia Diaspora Policy. Addis Ababa.

Organization for Economic Co-operation and Development /OECD/. (2016). International Migration in Shifting World: Perspectives on Global Development 2017. Paris: OECD Publishing Service.

Teferi, M. (2013). Rural Outmigration of Children and Youth and Impacts on Migrant-Sending Households in Gojam and Wolaita, Ethiopia (PhD dissertation). Addis Ababa University.

Tesfaye, T. (2003). Rural Lands and Evolving Tenure Arrangements in Ethiopia: Issues, Evidence and Policies (Discussion Paper 10). Addis Ababa: Forum for Social Studies.

Transparency International's (2015). Corruption Perceptions Index. Retrieved from https://www.transparency.org/cpi2015

United Nations Children's Fund /UNICEF/. (2014). Migration ProfilesCommon Set of Indicators, Ethiopia. Retrieved from https://esa.un.org/miggmgprofiles/indicators/indicators.HTM 
Messay Mulugeta and Tefree Makonnen

United Nations Children's Fund /UNICEF/. (2017). Ethiopia: Humanitarian Situation Report, Situation in Numbers. Addis Ababa.

United Nations Development Program /UNDP/. (2015). Accelerating Inclusive Growth for Sustainable Human Development in Ethiopia (National Human Development Report of 2014 for Ethiopia). Addis Ababa.

United Nations High Commissioner for Refugee /UNHCR/. (2016). Global Resettlement Needs ( $21^{\mathrm{st}}$ Annual Tripartite Consultations on Resettlement June 29-July 12015$)$. Geneva.

United Nations High Commissioner for Refugee /UNHCR/. (2017). Ethiopian Refugees and Asylum-Seekers. Geneva.

United Nations Office on Drug and Crime /UNODC/. (2008). International Framework for Action to Implement the Trafficking in Persons Protocol. Vienna.

United Nations, Department of Economic and Social Affairs /UNDESA/, Population Division. (2015). Trends in International Migrant Stock: The 2015 revision (United Nations database, POP/DB/MIG/Stock/Rev.2015). United Nations.

White, P. \& Woods R. (1980). The Geographical Impact of Migration. London: Longman Group Ltd.

Yonas, B. (2012). "Ethiopia's Paleoanthropological World Heritage sites: Research and conservation". In N., Sanz, editor. Human origin sites and the World Heritage Convention in Africa. Paris: the United Nations Educational, Scientific and Cultural Organization. 